Acta vet. scand. $1969,10,382-401$.

From the Institute for the Application of Nuclear Energy in Agriculture, Veterinary Medicine and Forestry, Zemun, Yugoslavia.*

\title{
SOME EFFECTS OF PROTEIN DEFICIENCY IN YOUNG GROWING PIGS
}

\section{THE SERUM PROTEIN SYSTEM * *}

\author{
By \\ J. A. Nikolić, M. Čuperlović and D. Stosić
}

Many data have been published about the effects of a deficiency of dietary protein upon the growth and weight of body organs, upon the metabolism of electrolytes and water (Platt et al. 1964), on nitrogen excretion (Hugot \& Causeret 1966), the blood protein system (Cartwright \& Wintrobe 1948, Barrows \& Chow 1959), and the free amino acids in blood plasma (Holt et al. 1963, Widdowson \& Whitehead 1966, Wikramanayake 1966, Edozien 1966) both in man and experimental animals. However, factors, such as the levels of fat, carbohydrates and vitamins in the diet and the age and species of animal, may influence the above parameters in addition to the shortage of protein. Thus, Albanese (1959) concluded that the concentrations of serum protein are not always dependable criteria of the nutritional state. Moreover, Munro (1964) states that "the course of protein metabolism is determined by a mosaic of interactions between the dietary supply of amino acids, the supply of energy yielding nutrients and the secretory activities of the endocrine glands". The investigations on the effects of dietary fat and

* In collaboration with the Department of Physiology, Endocrinology and Bloodgrouping, Royal Veterinary and Agricultural University, Copenhagen, Denmark.

** This investigation was supported in part by the Federal and Republic Fund for Coordination of Scientific Investigations, SFR Yugoslavia and by the United States Department of Agriculture, USA, Grant Contract no. PL 480. 
carbohydrate levels on protein deficiency symptoms in pigs and dogs by Platt et al. did not include the extremes of total starvation and complete protein deficiency.

The present paper describes a study on the effect of protein lack, both in the presence and absence of energy yielding nutrients, on serum protein components in young growing pigs.

\section{Animals}

\section{MATERIALS AND METHODS}

Twelve castrated male pigs of the Swedish Landrace type were divided into four groups so that no group contained animals from the same litter and each group had a similar average body weight. The swine were housed in pairs and fed with rations of $0.5 \mathrm{~kg}$ per pig twice daily.

\section{Experimental}

The semi-synthetic isocaloric diets (Table 1) contained similar and satisfactory amounts of minerals and vitamins.

T a b l e 1. Experimental diets.

\begin{tabular}{|c|c|c|}
\hline \multirow[t]{2}{*}{ Ingredients } & \multicolumn{2}{|c|}{ Amount included (\%) } \\
\hline & Diet 1 (protein suppl.) & Diet 2 (protein free) \\
\hline corn starch & 34.0 & 64.0 \\
\hline sucrose & 10.0 & 20.0 \\
\hline lactose & - & 4.0 \\
\hline skimmed milk powder & 46.0 & - \\
\hline corn oil & 4.5 & 4.5 \\
\hline fish oil & 0.5 & 0.5 \\
\hline cellulose & 3.0 & 3.0 \\
\hline microelement mixture $^{\star}$ & 1.0 & 1.0 \\
\hline vitamin mixture $^{\star \star}$ & 0.02 & 0.02 \\
\hline sodium chloride & 0.5 & 0.5 \\
\hline sodium diphosphate & 0.5 & - \\
\hline dicalcium phosphate & - & 2.5 \\
\hline protein content ( $\%$ dry weig & 14.88 & 1.10 \\
\hline digestible energy $(\mathrm{cal} / \mathrm{kg})$ & 3504 & 3420 \\
\hline \multicolumn{3}{|c|}{$\begin{array}{l}\text { Mixture composition }(\mathrm{g} / \mathrm{kg}): \mathrm{CuSO}_{4} \cdot 5 \mathrm{H}_{2} \mathrm{O}-3.93 ; \mathrm{FeSO}_{4} \cdot 7 \mathrm{H}_{2} \mathrm{O}- \\
40.0 ; \mathrm{KI}-0.026 ; \mathrm{MgSO}_{4} \cdot 7 \mathrm{H}_{2} \mathrm{O}-405.00 ; \mathrm{MnSO}_{4} \cdot \mathrm{H}_{2} \mathrm{O}-12.30 ; \mathrm{ZnSO}_{4} \\
7 \mathrm{H}_{2} \mathrm{O}-21.95 ; \mathrm{CaCO}_{3}-516.794 . \\
\text { * Mixture composition: } \mathrm{B}_{1}(100 \%)-1.10 ; \mathrm{B}_{2}(80 \%)-3.17 ; \mathrm{Niacin} \\
(100 \%)-13.20 ; \text { calcium pantothenate }(45 \%)-17.05 ; \mathrm{B}_{12}-(200 \mathrm{mg} / \\
\text { kg)-55.0; sucrose - } 110.48 .\end{array}$} \\
\hline
\end{tabular}


All the animals received Diet 1 for an adjustment period of five days. The treatments given to the pigs thereafter are summarized in Table 2.

Table 2. Treatments for the experimental period.

\begin{tabular}{lclc}
\hline Group & Number of pigs & Diet & Period (days) \\
\hline control (A) & 4 & Diet 1 & 84 \\
rehabilitation (B) & 3 & Diet 2 & 42 \\
& & Diet 1 & 42 \\
protein starvation (C) & 3 & Diet 2 & 84 \\
total starvation (D) & 2 & water and & \\
& & Ringer solution & 23 \\
\hline
\end{tabular}

After fasts of $16 \mathrm{hrs}$. the pigs were weighed and blood samples were taken from the jugular vein before the change to a semisynthetic diet, after the adjustment period and thereafter at fortnightly intervals for 84 days.

\section{Analyses}

Serum protein concentrations were measured on an Elko II colorimeter using the biuret reaction (Huerga et al. 1964).

Serum lipids were estimated gravimetrically (Friedman 1968). Weighing cups were made from aluminum foil, and it was found that at least 48 hrs.' desiccation was required for the lipid extract to be reduced to constant weight. The error of the method was estimated to be $\pm 13 \%$ based on seven determinations of the same serum.

Protein bound carbohydrate levels were estimated as galactose and mannose (Shetlar et al. 1948) using an Elko II colorimeter.

Sera were fractionated by paper electrophoresis according to the technique of Aronsson \& Grönwall (1957). The stained strips were examined on a Beckman Analytrol densitometer.

For polypeptide analysis, papers were stained with amidoblack (Amidoschwartz $10 \mathrm{~B}$, Merck, Darmstadt), which reacts with basic groups in the polypeptide moieties of the proteins (Badin \& Hervé 1965). The eight different fractions were designated albumin-1, albumin-2, $\alpha$-globulin-1, $\alpha$-globulin-2, $\alpha$-globulin-3, $\beta$-globulin-1, $\beta$-globulin-2 and $\gamma$-globulin. The standard error of a single determination based on 16 separate measurements of the same serum during the course of the experiment was $\pm 29 \%, \pm 8 \%, \pm 39 \%, \pm 21 \%$, $\pm 15 \%, \pm 19 \%, \pm 9 \%, \pm 10 \%$, for each fraction respectively.

Lipoproteins were detected by staining with sudanblack (Sudanschwarz-B, Merck, Darmstadt) according to the method of Hirsch \& Cathaneo (1956). Three fractions, namely $\alpha$-lipoprotein, $\beta$-lipo- 
protein and a chylomicron trail fraction were determined with an accuracy of $\pm 20 \%, \pm 18 \%$ and $\pm 20 \%$ respectively.

Protein bound carbohydrates were measured by staining papers with Schiff's reagent after oxidation with periodic acid (Bjornesjö 1955, Laurell \& Skoog 1956). Six different fractions corresponding to a combined albumin and $\alpha$-globulin-1 fraction, $\alpha$-globulin-2, $\alpha$-globulin-3, $\beta$-globulin-1, $\beta$-globulin-2 and $\gamma$-globulin fractions were separated. Errors of $\pm 44 \%, \pm 11 \%, \pm 5 \%, \pm 33 \%, \pm 22 \%$ and $\pm 17 \%$ were found in the determinations, respectively.

All analyses were performed in duplicate except in lipoprotein fractionation which was done in triplicate. Fig. 1 shows the interrelationships of the serum fractions determined by the three procedures.

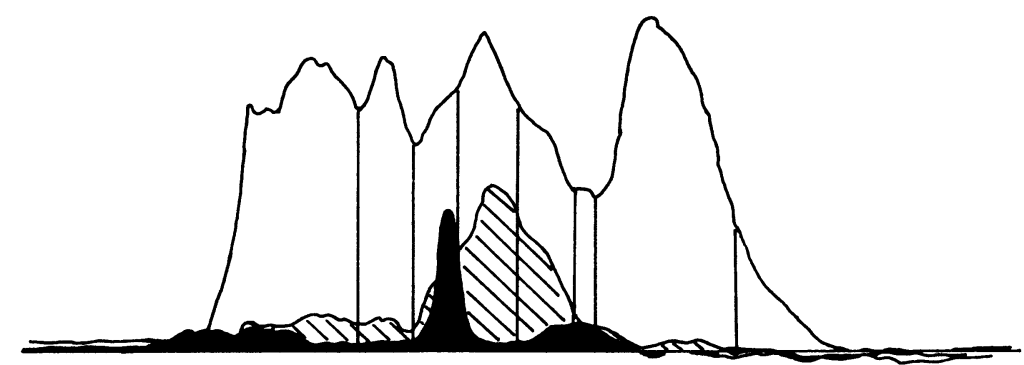

F i g u r e 1. Electropherogram of pig serum proteins. Strips from a single sheet were stained for polypeptides, $\square$; glycoproteins, and lipoproteins, $\square$. The vertical lines indicate the points of division into the various fractions. Direction of electrophoresis is from left to right.

\section{RESULTS}

\section{Appearance and body weight}

At the end of the three months' experimental period the control pigs (Group A) were strong, healthy and alert. The skin and hair were in good condition. One pig was killed accidentally during ferrokinetic studies in the last week of the investigation.

The two surviving rehabilitated pigs from Group B were in reasonable condition. They were noticeably shorter in the legs 
than the pigs in Group A. These pigs were less calm and handling induced such symptoms as flushing of the skin although most signs of keratosis had disappeared. One pig died 43 days after the start of the experiment. Pathological analyses revealed bronchopneumonia and bacterial infection, to which animals are susceptible when malnourished.

One pig from Group $\mathrm{C}$ was killed in a moribund condition after 70 days of protein deprivation. This animal had extensive oedema and was too weak to eat. The other two pigs were in poor condition with signs of oedema at the joints and rough hair. They consumed very little of the food offered.

The totally starved pigs rapidly assumed a wasted appearance with a brown leathery skin. These pigs were killed after 23 days when one was in bad condition.

The control Group A showed a continuous increase in weight (Table 3), which necessitated an increase in the food ration to $1 \mathrm{~kg}$ per animal twice daily. Group $\mathrm{C}$, which received the protein deficient diet throughout the 84 days' experimental period,

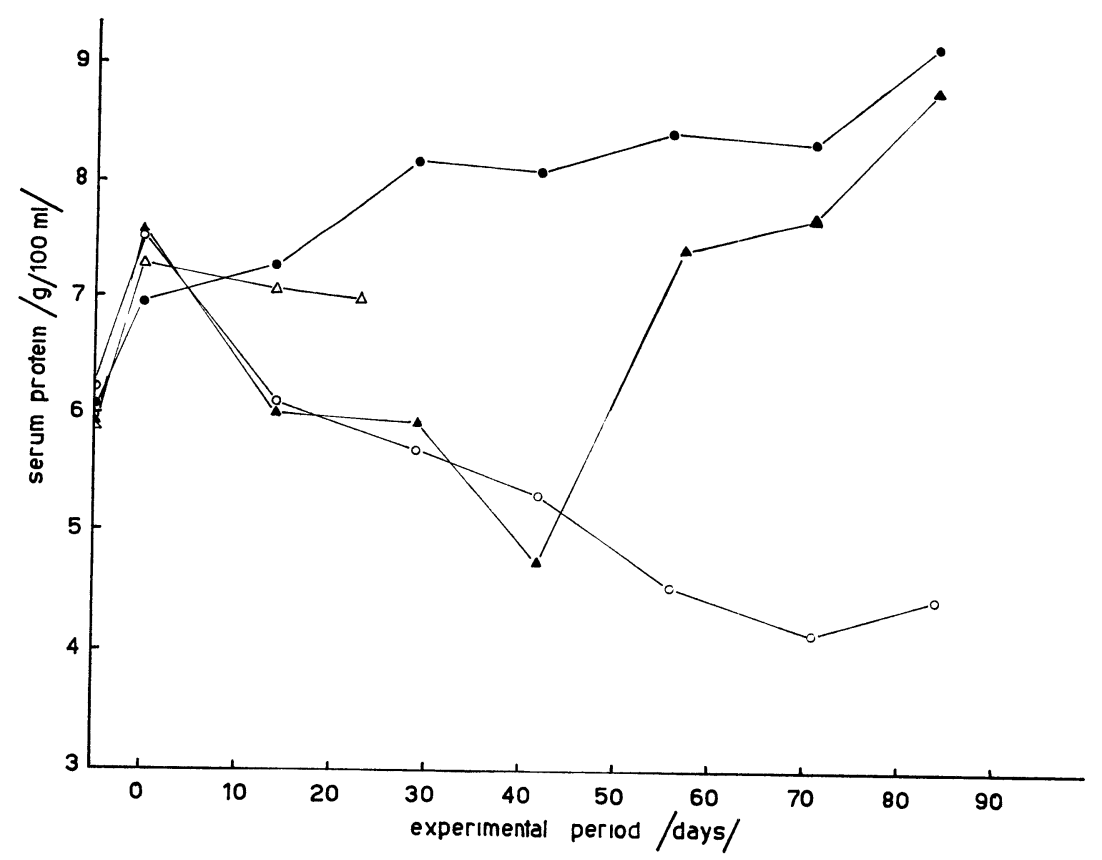

F i g u r e 2. Serum protein levels of pigs subjected to different dietary treatments. Group A, control, $\bullet$; group B, protein deprived 42 days, rehabilitated 42 days, $\triangle$; group $C$, protein deprived 84 days, $\bigcirc$; and group D, starved, $\triangle$. 


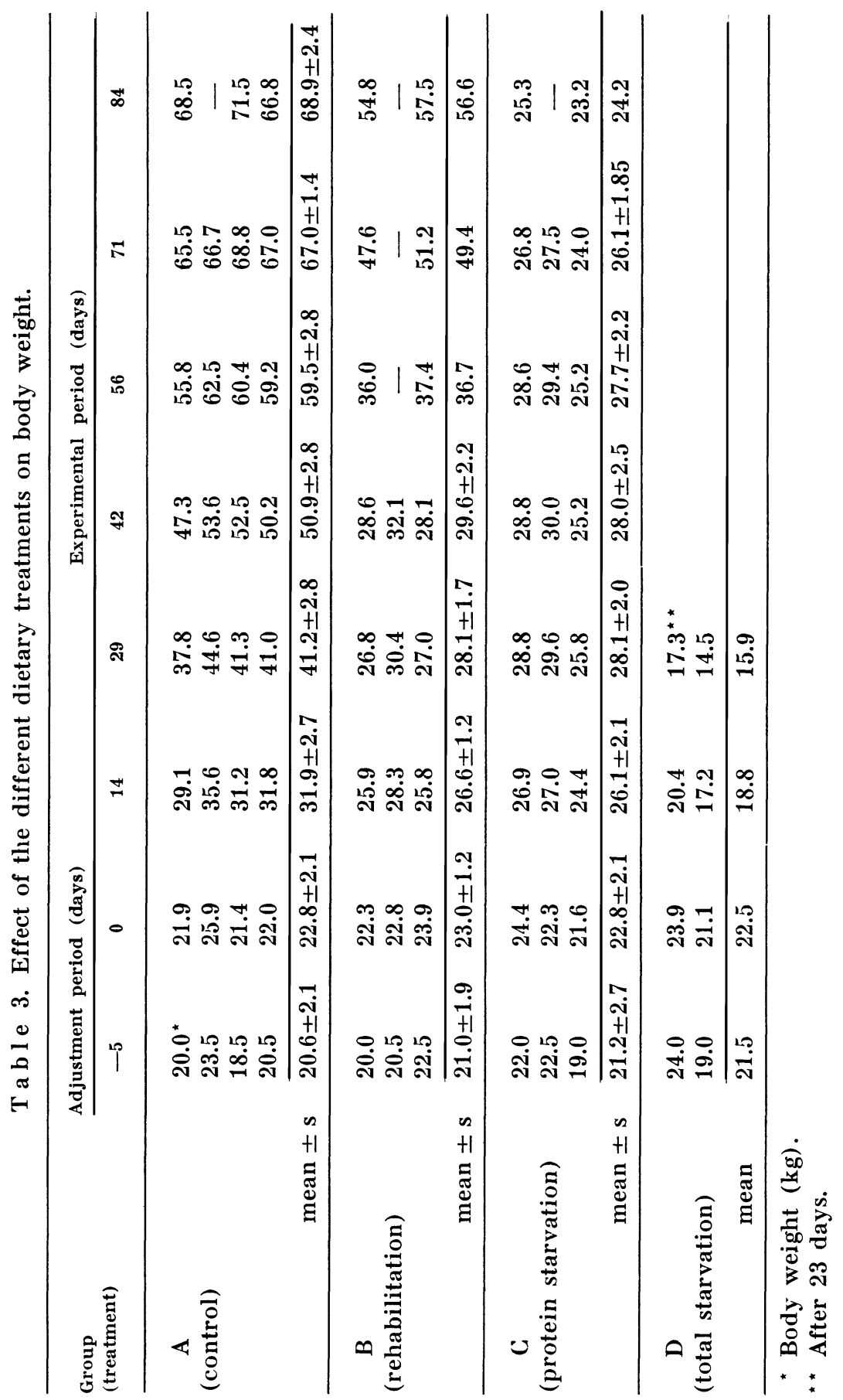


exhibited a small gain in weight during the first few weeks followed by a slight fall. A similar pattern was found with the pigs of Group B until a protein supplement was added to the diet after 42 days. Although rapid increases in body weights occurred, the final levels were still $12.3 \mathrm{~kg}$ less than the average value for Group A (Table 3). The totally starved pigs lost weight continuously.

\section{Total protein}

An immediate increase of about $18 \%$ was noted in the serum protein levels of all groups during the adjustment period (Fig. 2). Thereafter control pigs (Group A) showed a continuous increase over the whole experimental period with a total gain of more than $2 \mathrm{~g}$ protein per $100 \mathrm{ml}$ serum.

The slight fall in protein concentrations of Group $D$ was not significant. Groups B and C showed a rapid decrease in serum protein concentration during the first 42 day starvation period to values significantly less than control levels $(P<0.001)$ and initial levels $(P<0.01)$. A further slight fall occurred in Group $\mathrm{C}$ during the second starvation period. On the contrary, the rehabilitated Group B exhibited a rapid increase in serum protein concentration which almost reached control levels at the end of the experimental period.

\section{Polypeptide fractions}

There were only minor differences between the initial concentrations of the serum protein fractions (Figs. 3, 4, 5 and 6). During the adjustment period the levels of most fractions rose in all groups. Thereafter, the albumin concentrations of the control pigs (Group A) were relatively constant (Fig. 3). In Groups $B$ and $C$ albumin-2 concentrations fell rapidly during the first 42 day protein free period and were significantly lower than control values $(P<0.01)$ and initial values in the same group. On refeeding with Diet 1 , Group $B$ showed a rapid increase in albumin-2 concentrations, which had reattained control levels at the end of the experimental period whereas the final level in Group $\mathrm{C}$ was about one third the value. The albumin-1 fraction showed similar variations (Fig. 3) except that the response to dietary changes appeared to be slower and less profound. Despite the large error in measurement, differences between the control and protein starved pigs were significant 


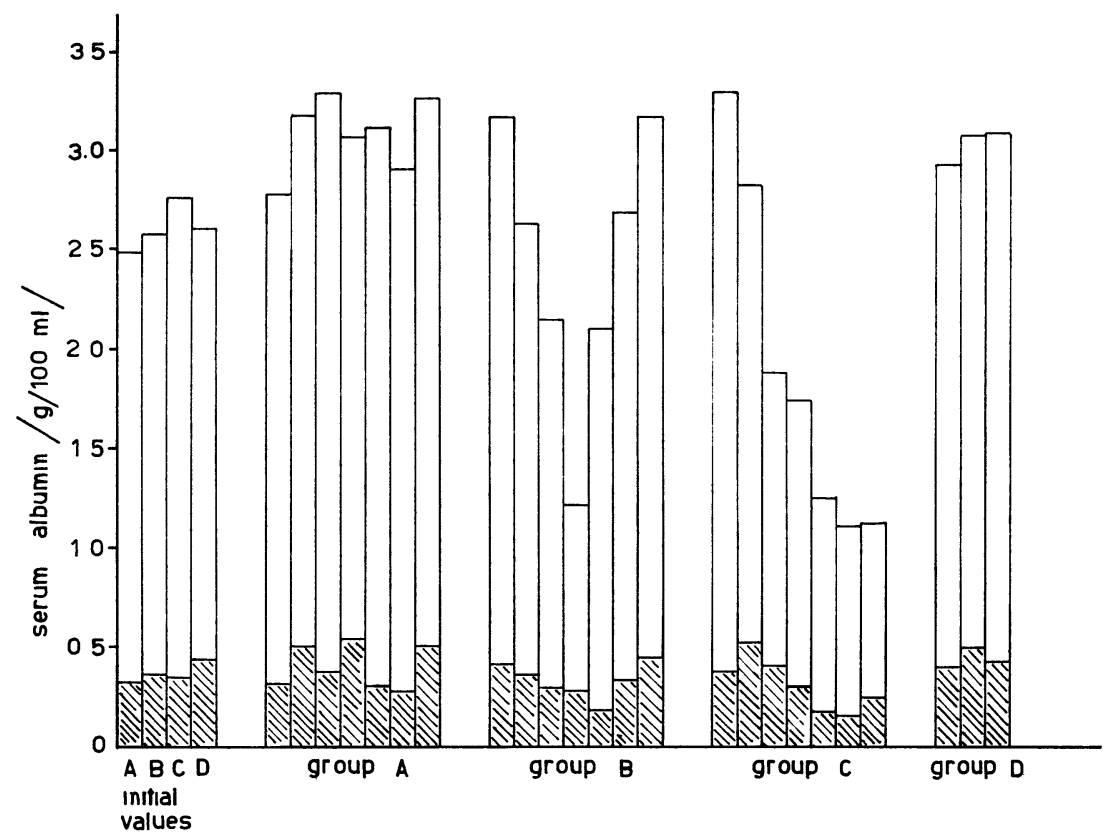

F i g u r e 3. Serum albumin concentrations, albumin-1, YI/l/, albumin-2, $\square$, at fortnightly intervals in pigs undergoing various dietary treatments. Group A, control; group B, protein deprived 42 days, rehabilitated 42 days; group $\mathrm{C}$, protein deprived 84 days; and group $\mathrm{D}$, starved. The first block shows the albumin levels before the pigs received the semisynthetic diet.

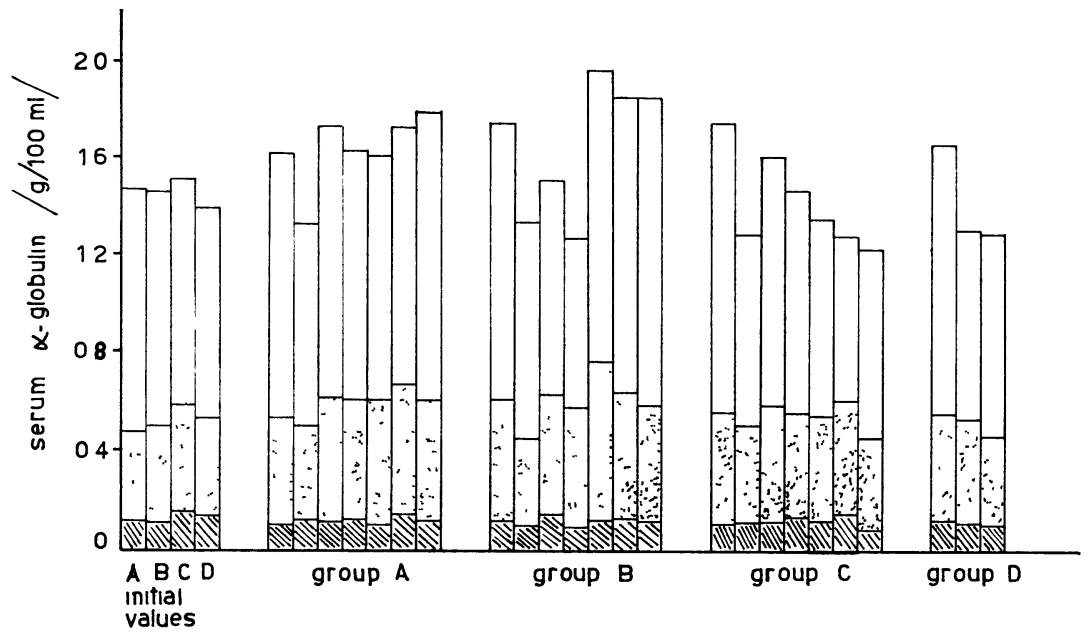

F i g u r e 4. Serum $\alpha$-globulin concentrations, $\alpha$-globulin-1, $\alpha$-globulin-2, $\square$; $\alpha$-globulin-3, $\square$, at fortnightly intervals in pigs undergoing various dietary treatments (cf. Fig. 3). 


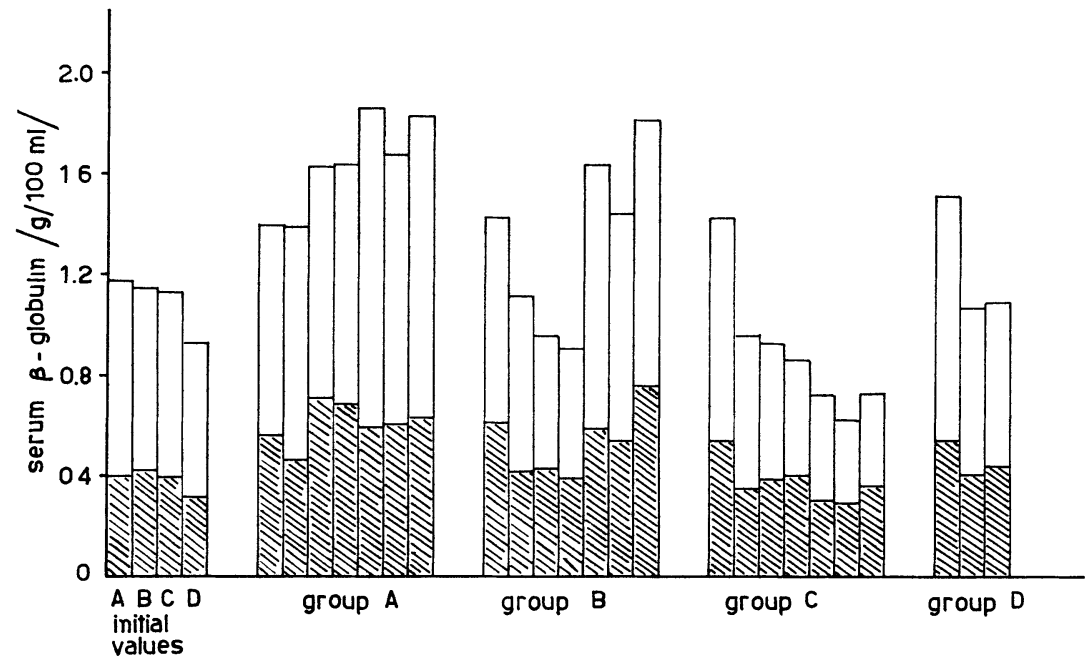

Fig u r e 5. Serum $\beta$-globulin concentrations, $\beta$-globulin-1, $\beta$; $\beta$-globulin-2, $\square$, at fortnightly intervals in pigs undergoing various dietary treatments (cf. Fig. 3).

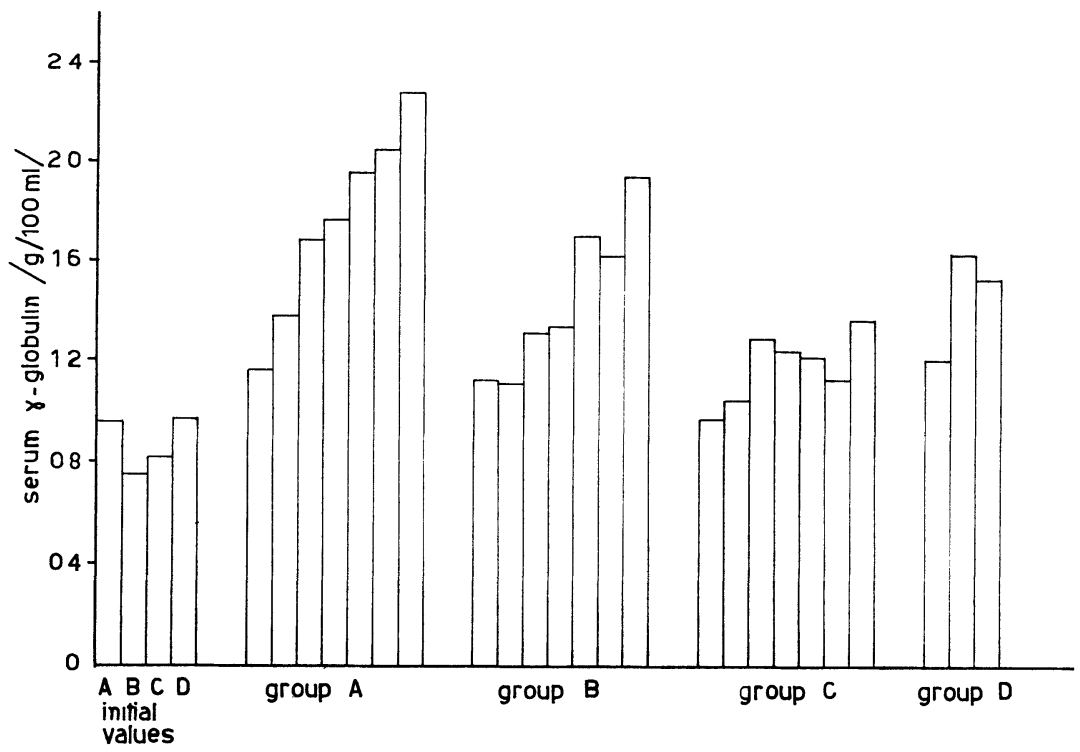

Figure 6. Serum $\gamma$-globulin concentrations at fortnightly intervals in pigs undergoing various dietary treatments (cf. Fig. 3). 
$(P<0.01)$. The concentrations of the albumin fractions in the totally starved pigs remained in the control range.

The small $\alpha$-globulin-1 fraction appeared to be unaffected by the dietary conditions (Fig. 4). The $\alpha$-globulin-2 fraction was also fairly stable although a reduction to four fifths of control levels was noted in Group $C$ towards the end of the experiment. Both this fraction and $\alpha$-globulin-3 showed immediate rises when Group B was refed with a protein containing diet. After one month $\alpha$-globulin-2 levels had returned to normal, but $\alpha$-globulin-3 concentrations remained elevated. Under conditions of protein starvation the $\alpha$-globulin-3 fraction started to decrease in concentration only after one month of the protein free diet. Final levels of this fraction in Group $\mathrm{C}$ were two thirds those of Group A $(P<0.05)$. Total starvation also appeared to induce a reduction in $\alpha$-globulin levels.

Immediate falls in both $\beta$-globulin fractions were noted in Groups $\mathbf{B}$ and $\mathbf{C}$ during the first fortnight of protein starvation (Fig. 5). The final levels of the $\beta$-globulin-1 and the $\beta$-globulin-2 fractions of Group $C$, were one half and one third of control values respectively $(\mathrm{P}<0.05 ; \mathrm{P}<0.01)$. On refeeding Group $\mathrm{B}$ with a protein containing diet immediate rises were noted in both fractions, which had reached control levels in the case of $\beta$-globulin-1 after 14 days. By the end of the experiment control levels of $\beta$-globulin-2 had also been reattained.

All animals showed a rise in $\gamma$-globulin levels during the experimental periods (Fig. 6). In the milk protein fed pigs (Group A) the increase was almost linear. An increase followed by a slight fall was observed with the totally starved pigs (Group D). Under conditions of protein starvation the $\gamma$-globulin levels rose at a slow rate during the second period (Group C). Group B showed two rates of increase in $\%$-globulin levels (Fig. 6), namely a slow one during the starvation period and a rate similar to that of Group A during the refeeding period. The final difference between the $\gamma$-globulin concentrations of Group A and B accounts for the slightly lower total protein levels in the latter group.

\section{Glycoproteins}

The results of the determinations of serum protein bound carbohydrate are shown in Table 4 . In calculating values for the various fractions it has been assumed that each fraction contains the same ratio of hexose to sialic acid (Winzler 1960) which has 
T a b l e 4. Effect of diet on protein bound carbohydrate in pig serum.*

\begin{tabular}{|c|c|c|c|c|}
\hline \multirow{2}{*}{$\begin{array}{l}\text { Group } \\
\text { (treatment) }\end{array}$} & \multirow[t]{2}{*}{ Fraction } & \multicolumn{3}{|c|}{ Duration of experiment (days) } \\
\hline & & 0 & 42 & 84 \\
\hline \multirow{7}{*}{$\underset{\text { (control) }}{\mathrm{A}}$} & albumin $+\alpha$-globulin-1 & $13(10-14)$ & $14(8-17)$ & $11(9-14)$ \\
\hline & $\alpha$-globulin-2 & $25(21-30)$ & $27(19-41)$ & $23(19-27)$ \\
\hline & $\alpha$-globulin-3 & $55(43-62)$ & $47(33-57)$ & $44(42-47)$ \\
\hline & $\beta$-globulin-1 & $23(18-26)$ & $28(24-39)$ & $25(23-26)$ \\
\hline & $\beta$-globulin-2 & $14(13-15)$ & $13(11-16)$ & $14(11-15)$ \\
\hline & $\gamma$-globulin & $18(12-22)$ & $23(18-28)$ & $26(21-33)$ \\
\hline & total & $147(132-166)$ & $151(127-187)$ & $142(137-151)$ \\
\hline \multirow{7}{*}{$\stackrel{\text { B }}{\text { (rehabilitation) }}$} & albumin $+\alpha$-globulin-1 & $17(7-23)$ & $12(10-13)$ & $13(12-14)$ \\
\hline & $\alpha$-globulin-2 & $26(19-31)$ & $29(25-28)$ & $27(24-30)$ \\
\hline & $\alpha$-globulin-3 & $59(51-66)$ & $42(38-46)$ & $59(54-64)$ \\
\hline & $\beta$-globulin-1 & $17(15-19)$ & $19(14-22)$ & $29(28-29)$ \\
\hline & $\beta$-globulin-2 & $13(12-13)$ & $9(8-10)$ & $13(12-14)$ \\
\hline & $\gamma$-globulin & $19(16-20)$ & $27(25-29)$ & $19(14-25)$ \\
\hline & total & $150(133-165)$ & $138(121-148)$ & $160(155-165)$ \\
\hline \multirow{8}{*}{\begin{tabular}{l}
\multicolumn{1}{c}{ C } \\
(protein \\
starvation)
\end{tabular}} & albumin $+\alpha$-globulin-1 & $15(11-17)$ & $11(9-15)$ & $9(9)$ \\
\hline & $\alpha$-globulin-2 & $36(33-41)$ & $24(22-27)$ & $26(24-29)$ \\
\hline & $\alpha$-globulin-3 & $59(50-70)$ & $50(47-54)$ & $44(41-47)$ \\
\hline & $\beta$-globulin-1 & $23(16-31)$ & $19(18-20)$ & $22(18-26)$ \\
\hline & $\beta$-globulin-2 & $14(11-17)$ & $7(4-9)$ & $8(6-10)$ \\
\hline & $\gamma$-globulin & $19(18-20)$ & $24(19-28)$ & $27(20-33)$ \\
\hline & total & $164(147--186)$ & $134(120-142)$ & $136(123-143)$ \\
\hline & & \multicolumn{3}{|c|}{23 days } \\
\hline \multirow{7}{*}{$\begin{array}{l}\quad \text { D } \\
\text { (total } \\
\text { starvation) }\end{array}$} & albumin $+\alpha$-globulin-1 & $17(12-23)$ & $13(13-14)$ & \\
\hline & $\alpha$-globulin-2 & $41(30-52)$ & $26(20-32)$ & \\
\hline & $\alpha$-globulin-3 & $57(52-61)$ & $32(22-42)$ & \\
\hline & $\beta$-globulin-1 & $28(21-35)$ & $30(30)$ & \\
\hline & $\beta$-globulin-2 & $13(9-17)$ & $12(11-13)$ & \\
\hline & $\gamma$-globulin & $18(13-23)$ & $25(24-25)$ & \\
\hline & total & $175(148-201)$ & $138(135-141)$ & \\
\hline
\end{tabular}

* $\mathrm{mg} / 100 \mathrm{ml}$ serum.

been postulated to be the moiety measured by the Schiff reagent (Montreuil \& Biserte 1959).

The trends that emerge from the data presented in Table 4 are similar to those indicated by polypeptide analysis. Thus the fractions corresponding to albumin and $\beta$-globulin-2 decreased 
in concentration in the protein starved groups and the fall was reversed on refeeding with protein. Levels of $\gamma$-globulin glycoproteins increased in all groups. $\alpha$-globulin-3 appeared to be slightly elevated in the refed pigs at the end of the experiment but to be reduced in totally starved pigs. Shetlar \& Shetlar (1955) found that serum protein bound polysaccharide levels were reduced in starved rats. Thus these data indicate that the changes in the serum proteins are quantitative rather than qualitative.

\section{Serum lipids}

$A$ rise in the serum lipids, largely due to a $50 \%$ increase in $\beta$-lipoprotein lipid, was noted in the control pigs during the experimental period (Table 5). A fall in this fraction accom-

T a ble 5. Effects of diet on serum lipids in pigs. *

\begin{tabular}{|c|c|c|c|c|}
\hline \multirow{2}{*}{$\begin{array}{l}\text { Group } \\
\text { (treatment) }\end{array}$} & \multirow[t]{2}{*}{ Lipid fraction } & \multicolumn{3}{|c|}{ Duration of experiment (days) } \\
\hline & & ? & 42 & 84 \\
\hline \multirow{4}{*}{$\underset{\text { (control) }}{\mathrm{A}}$} & $\alpha$-lipoprotein & $153(134-188)$ & $137(96-190)$ & $176(151-180)$ \\
\hline & $\beta$-lipoprotein & $179(133-206)$ & $206(169-260)$ & $267(226-321)$ \\
\hline & trail fraction & $251(234-269)$ & $242(178-450)$ & $241(191-265)$ \\
\hline & total & $583(515-630)$ & $584(485-842)$ & $684^{* *}(673-710)$ \\
\hline \multirow{4}{*}{$\stackrel{\text { B }}{\text { (rehabilitation) }}$} & $\alpha$-lipoprotein & $170(152-191)$ & $70^{*}(61-90)$ & $159(154-164)$ \\
\hline & $\beta$-lipoprotein & $229(195-298)$ & $128(66-269)$ & $335(283-389)$ \\
\hline & trail fraction & $256(183-298)$ & $160(109-179)$ & $197(181-208)$ \\
\hline & total & $655(540-780)$ & $357^{*}(245-520)$ & $690(655-724)$ \\
\hline \multirow{5}{*}{\begin{tabular}{l}
\multicolumn{1}{c}{$\mathrm{C}$} \\
(protein \\
starvation)
\end{tabular}} & $\alpha$-lipoprotein & $142(125-161)$ & $124(105-146)$ & $56(35-73)$ \\
\hline & $\beta$-lipoprotein & $234(214-269)$ & $165(114-168)$ & $128(78-173)$ \\
\hline & trail fraction & $234(220-259)$ & $252(263-282)$ & $184(97-259)$ \\
\hline & total & $610(575-650)$ & $541(480-645)$ & $358^{* *}(210-505)$ \\
\hline & & \multicolumn{3}{|c|}{23 days } \\
\hline \multirow{4}{*}{$\begin{array}{l}\stackrel{D}{1} \\
\text { (total } \\
\text { starvation) }\end{array}$} & $\alpha$-lipoprotein & $108(88-129)$ & $145(128-157)$ & \\
\hline & $\beta$-lipoprotein & $215(180-251)$ & $241(192-294)$ & \\
\hline & trail fraction & $250(222-275)$ & $374(349-397)$ & \\
\hline & total & $573(490-655)$ & $760(700-820)$ & \\
\hline
\end{tabular}

* $\mathrm{mg} / 100 \mathrm{ml}$ serum.

* Difference significant from control $(\mathrm{P}<0.05)$. 
panied by a greater decrease in $\alpha$-lipoprotein lipid, and a reduction in the chylomicron trail fraction was observed in the protein deprived groups. At the end of the experiment the values for Group B had returned to control regions. Both protein starved pigs which failed to survive the planned experimental period showed a rise in $\beta$-lipoprotein just before death. An increase in serum lipid concentrations resulting mainly from an increase in the chylomicron trail fraction was found in the total starvation group.

\section{DISCUSSION}

The weight differences manifested by the different groups of pigs are a striking indication of the effects of protein deficiency and total starvation in young growing animals. The sparing effect of nutrition with a protein-free diet is immediately apparent. However, more profound adaptations may occur with a protein deficient diet than with total starvation, such as the immediate large drop in serum protein concentrations. Also, the effects of total starvation may be opposite in character to those of protein starvation, which is one reason for the clinical difficulties is classifying protein/caloric malnutrition diseases. Thus serum lipid concentrations increased under total starvation but decreased during protein deficiency. Other differences will be discussed in the following reports.

The responses of the various serum protein fractions to protein deprivation can be divided into three groups. The first group containing albumin and $\beta$-globulins responds rapidly to a protein lack with concentrations falling to values less than half the normal (Figs. 3 and 5 ). As far as albumin is concerned the studies of Kirsch et al. (1968) with rats indicate that a reduction or withdrawal of dietary protein primarily causes a reduction in the synthesis rate. Reduction in catabolism only follows when the concentration of albumin is already lowered. This is supported by our data which show that the plasma albumin concentration in Group $\mathrm{C}$ falls much less rapidly during the second half of the experiment. On refeeding with protein the reverse situation occurs. Thus, the effect of protein deficiency on serum albumin is possibly mediated via the liver where albumin synthesis has been established to occur (Le Bouton 1968). 
The $\beta$-globulin-1 zone on electropherograms contains $\beta$-lipoprotein (Fig. 1) and both measurements of polypeptide and lipid concentrations indicate that this fraction is affected by diet. The iron binding protein transferrin is a major component of the $\beta$-globulin-2 fraction (Panic \& Ekman 1967). This fraction was affected by protein deficiency to the same degree as albumin and, since albumin and $\beta$-lipoprotein also have important transport functions, a severe dislocation of the transport of many substances may be envisaged to occur under conditions of protein starvation. The fact that the severity of the effect of protein starvation on lipoproteins is in inverse proportion to the protein content of the lipoprotein fractions indicates that the conservation of protein is the prime reason for the lowered levels (Olson \& Vester 1960).

The second group of proteins comprises the $\alpha$-globulins which include ceruloplasmin, the copper binding protein, haptoglobins, prothrombin and the macroglobulins. The finding of lowered serum copper levels in protein starved pigs (Hristic 1968) supports the electrophoresis data that at least some proteins of this group are affected by protein deprivation. Losses of $\alpha$-globulins have been reported in protein depleted rats (Weimer et al. $1959 \mathrm{a}, \mathrm{b}) . \alpha$-globulins can be elevated by stress producing conditions which may explain the increases found in the pigs in Group B after sudden refeeding with protein (Petermann 1960, Dimopoullos 1963).

$\gamma$-globulins which form the third group are affected least by dietary protein levels. Synthesis of $\gamma$-globulins occurs in the reticuloendothelial system in contrast to other serum proteins (Birke 1966). Benditt et al. (1949) found that after an antigenic challenge the production of new antibody in protein deprived rats was severely restricted, which is consistent with our results. A similar large increase in $\gamma$-globulin levels as occurred in the control pigs of Group A has been reported in normal pigs during the age range of two to five months (Miller et al. 1961).

The net increase in serum protein levels during the three month experimental period was also similar to that observed by Miller et al., but our results were consistently higher than normal following the abrupt increase during the five day dietary adjustment period (Knill et al. 1958). This appears to be an effect of the semisynthetic diet, but, although haemoconcentration is a plausible explanation for the initial reaction, haematocrit and 
plasma volume values determined near the end of the experimental period were normal (Bush et al. 1955).

The possibility that some of the differences in serum protein levels are the result of changes in plasma volume is discounted when the levels of the total circulating plasma protein per $\mathrm{kg}$ body weight are compared among different groups of pigs (Table 6). The results from the control groups in two experi-

Table 6. The effect of protein deficiency on total circulating proteins. Data from two experiments.

\begin{tabular}{|c|c|c|c|c|c|c|}
\hline \multirow[t]{2}{*}{ Treatment } & \multirow[t]{2}{*}{ Pig no. } & \multicolumn{5}{|c|}{ Protein fractions $(\mathrm{g} / \mathrm{kg})$} \\
\hline & & albumin & $\alpha$-globulin & $\beta$-globulin & $\gamma$-globulin & total protein \\
\hline \multicolumn{7}{|l|}{ Experiment 1} \\
\hline casein & B & 1.55 & 0.88 & 0.75 & 0.96 & 4.14 \\
\hline control & $\mathrm{H}$ & 1.50 & 1.02 & 0.69 & 0.95 & 4.16 \\
\hline \multicolumn{7}{|l|}{ protein } \\
\hline starvation & G & 0.88 & 0.61 & 0.38 & 0.46 & 2.32 \\
\hline 38 days & $\mathrm{E}$ & 0.55 & 0.56 & 0.39 & 0.31 & 1.82 \\
\hline \multicolumn{7}{|l|}{ Experiment 2} \\
\hline \multicolumn{7}{|l|}{ protein } \\
\hline starvation & 3 & 0.54 & 0.61 & $0.47^{\star}$ & 0.61 & 2.24 \\
\hline 77 -78 days & 17 & 0.53 & 0.94 & $0.53^{\star}$ & 0.98 & 2.92 \\
\hline \multicolumn{7}{|l|}{ protein } \\
\hline starvation & 8 & 1.66 & 0.91 & $0.92^{\star}$ & 0.89 & 4.38 \\
\hline \multicolumn{7}{|l|}{42 days } \\
\hline rehabilitation & & & & & & \\
\hline 42 days & 14 & 1.27 & 0.51 & $0.66^{\star}$ & 0.74 & 3.20 \\
\hline milk protein & 7 & 1.82 & 0.76 & $1.34^{\star}$ & 1.04 & 4.96 \\
\hline control & 18 & 1.24 & 0.62 & $0.92^{\star}$ & 0.83 & 3.60 \\
\hline
\end{tabular}

* Fibrinogen included.

ments and the rehabilitated animals are similar, although the individual variation between animals is high. Lower levels of total circulating plasma protein per $\mathrm{kg}$ body weight were found in all the protein starved pigs. Definite effects on the albumin and $\beta$-globulin fractions are apparent. Weimer et al. (1959 a, b) have shown that plasma volume changes are only rarely of such magnitude as to mask the effect of various starvation regimes on serum protein concentrations. 


\section{ACKNOWLEDGMENTS}

The authors wish to thank Professor J. Moustgaard, Royal Veterinary and Agricultural University, Copenhagen, Denmark, for advice and encouragement, and colleagues in Zemun for useful discussions.

\section{REFERENCES}

Albanese, A. A.: Criteria of protein nutrition. In Protein and Amino Acid Nutrition. ed. A. A. Albanese, Academic Press, New York 1959, 297-347.

Aronsson, T.\& A. Grönwall: Improved separation of serum proteins in paper electrophoresis, a new electrophoresis buffer. Scand. J. clin. Lab. Invest. 1957, 9, 338-341.

Badin, J. \& B. Hervé: La précipitation des proteines par l'amidoschwarz et son application au microdosage des proteines seriques. (The precipitation of proteins by amidoblack and its application to the microdosage of serum proteins). Ann. Biol. clin. $1965,23,321-332$.

Barrows, C. H. \& B.F. Chow: Dietary proteins and synthesis of tissue proteins. In Protein and Amino Acid Nutrition. ed. A. A. Albanese, Academic Press, New York 1959, 117-142.

Benditt, E. P., R. W. Wissler, R. L. Woolbridge, D. A. Rowley \& C. H. Steffee, Jr.: Loss of body protein and antibody production by rats on low protein diets. Proc. Soc. exp. Biol. (N.Y.) 1949, 70, $240-243$.

Birke, G.: Factors regulating the plasma protein levels in normal and pathological conditions. In Protides of the Biological Fluids. ed. H. Peeters, Elsevier, Amsterdam 1966, vol. 14, 253-266.

Bjornesjö, K. B.: Staining of protein bound serum polysaccharides on electrophoresis strips. Scand. J. clin. Lab. Invest. 1955, 7, 153159.

Bush, J. A., W. N. Jensen, G. E. Cartwright \& M. M. Wintrobe: Blood volume studies in normal and anemic swine. Amer. J. Physiol. $1955,181,9-14$.

Cartwright, G. E. \& M. M. Wintrobe: Studies on free erythrocyte protoporphyrin, plasma copper and plasma iron in protein deficient and iron deficient swine. J. biol. Chem. 1948, 176, $571-583$.

Dimopoullos, G. T.: Plasma proteins. In Clinical Biochemistry of Domestic Animals. ed. C. E. Cornelius \& J. J. Kaneko. Academic Press, New York 1963, 110-201.

Edozien, J. C.: The free amino acids of plasma and urine in kwashiorkor. Clin. Sci. 1966, 31, 153--166.

Friedman, $H$. S.: Quantitative determination of total lipids in serum. Clin. chim. Acta 1968, 19, 291-295.

Hirsch, A. \& C. Cathaneo: Beitrag zur Frage der Untersuchung der Lipoidfraktionen des Blutserums. (Contribution to the determination of the lipoidfraction of blood serum). Klin. Wschr. 1956, 34, 581-584. 
Holt, L. E., S. E. Snyderman, P. H. Norton, E. Roitman \& J. Finck: The plasma aminogram in kwashiorkor. Lancet 1963, II, 1343.

Hristić, V.: Personal communication 1968.

Huerga, J. de la, G. W. Smetters \& J. C. Sherrick: Colorimetric determination of serum proteins: the biuret reaction. In Serum Proteins and the Dysproteinemias. ed. F. W. Sunderman \& F. W. Sunderman Jr., Pitman Medical, London 1964, 52-65.

Hugot, D. \& J. Causeret: Effets comparés d'un régime protéiprive et d'un régime contenant une petite quantité des proteines d'oeuf sur l'excretion d'azote chez le rat. (Comparison of the effects of a protein free regimen and a regimen containing a small amount of egg protein on the excretion of nitrogen in the rat). Ann. Biol. anim. 1966, 6, 179-188.

Kirsch, R., L. Frith, E. Block \& R. Hoffenburg: Regulation of albumin synthesis and catabolism by alteration of dietary protein. Nature (Lond.) 1968, 217, 578-579.

Knill, L. H., T. R. Podleski \& W. A. Childs: Normal values of swine serum proteins. Proc. Soc. exp. Biol. (N.Y.) 1958, 97, 224-226.

Laurell, C. B. \& N. Skoog: Staining of protein bound carbohydrate after electrophoresis of serum on filter paper. Scand. J. clin. Lab. Invest. 1956, 8, 21-25.

Le Bouton, A. V.: Precursor-product relationship between intrahepatic albumin and plasma albumin. Biochem. J. 1968, 106, 503-506.

Miller, E. R., D. E. Ullrey, I. Ackerman, D. H. Schmidt, J. A. Hoeffer $\& R$. W. Luecke: Swine haematology from birth to maturity. I. Serum proteins. J. Animal Sci. 1961, 20, 31-35.

Montreuil, J. \& G. Biserte: Acide sialique et specificité de la reaction l'acide periodique-fuchsine de Schiff appliqueé a l'électrophorése sur la papier. (Sialic acid and the specificity of the periodic acid/fuchsin reaction of Schiff applied to paper electrophoresis). Bull. Soc. Chim. biol. (Paris) 1959, 41, 959-973.

Munro, $H$. N.: General aspects of the regulation of protein metabolism, by diet and by hormones. In Mammalian Protein Metabolism. ed. H. N. Munro \& J. B. Allison, Academic Press, New York 1964, vol. 1, 381-481.

Olson, R. E. \& J. W. Vester: Nutrition-endocrine interrelationships in the control of fat transport in man. Physiol. Rev. 1960, 40, 677-733.

Panić, B. \& L. Ekman: Vezivanje mangana za serum proteina kod domaćih životinja. (Binding of manganese to the serum proteins of domestic animals). Acta vet. (Beogr.) 1967, 17, 167-174.

Petermann, H. L.: Alterations in plasma protein patterns in disease. In The Plasma Proteins. ed. F. W. Putnam, Academic Press, New York 1960, vol. 2., 309-343.

Platt, B. S., C. R. C. Heard \& R. J. C. Stewart: Experimental protein calorie deficiency. In Mammalian Protein Metabolism. ed. H. N. Munro \& J. B. Allison, Academic Press, New York 1964, vol. 2, $445-521$. 
Shetlar, M. R., J. V. Foster \& M. R. Everett: Determination of serum polysaccharides by the tryptophan reaction. Proc. Soc. exp. Biol. (N.Y.) 1948, 67, 125-130.

Shetlar, M. R. \& C. L. Shetlar: Effect of cortisone on serum glycoprotein and seromucoid levels of rats. Proc. Soc. exp. Biol. (N.Y.) $1955,88,622-624$.

Weimer, H. E., R. T. Bell \& H. Nishihara: Dietary protein and serum electrophoretic patterns of the adult rat. Proc. Soc. exp. Biol. (N.Y.) 1959 a, 100, 853-855.

Weimer, H. E., R. T. Bell \& H. Nishihara: Effects of protein depletion and repletion on serum electrophoretic patterns of adult rats. Proc. Soc. exp. Biol. (N.Y.) 1959 b, 102, 689-691.

Widdowson, E. M. \& R. G. Whitehead: Plasma amino acid ratio and urinary hydroxyproline excretion in rats deficient in protein and calories. Nature (Lond.) 1966, 212, 683-686.

Wikramanayake, T. W.: Protein malnutrition in the rat induced by protein-caloric imbalance. Brit. J. Nutr. 1966, 20, 641-648.

Winzler, R. H.: Glycoproteins. In The Plasma Proteins. Vol. 1. ed. F. W. Putnam, Academic Press, New York 1960, 309-347.

\section{SUMMARY}

No significant differences between the serum protein concentrations of the totally starved pigs and control animals given a milk protein supplemented diet were found. Serum lipid levels rose in the totally starved group. During the first 42 days of the experimental period sharp falls in serum protein concentrations were noted in the protein deprived pigs. The losses were greatest in the albumin and two $\beta$-globulin fractions. $\gamma$-globulin levels rose but at a much slower rate than in the control group. In the pigs which were refed a protein containing diet during the second 42 day period, the concentrations of all the serum protein fractions except for $\gamma$-globulin had reached control levels by the end of the investigation. The pigs which continued with the protein free diet showed further losses of albumin, a reduction in some $\alpha$-globulin fractions and a cessation of net $\gamma$-globulin synthesis. The trends observed by measurements of protein bound carbohydrate were similar to those obtained from polypeptide determinations indicating quantitative rather than qualitative changes in the serum proteins. The reduction in the serum lipid concentrations of the pigs undergoing protein starvation was largely accounted for by losses of $\alpha$ - and $\beta$-lipoproteins. The protein deprived pigs maintained their initial body weight, while a continuous fall in weight was found in the totally starved group and a continuous increase in the control pigs. 


\section{ZUSAMMENFASSUNG \\ Einige Folgen von Eiweissmangel bei Ferkeln. I. Das Serumeiweiss- system.}

Es wurden keine signifikanten Unterschiede zwischen den Serumeiweisskonzentration bei total ausgehungerten Ferkeln und bei Kontrolltieren, die ein mit Milcheiweiss bereichertes semi-synthetisches Futter erhielten, festgestellt. Das Niveau der Serumlipide stieg bei der total ausgehungerten Gruppe. Während der ersten Tage des 42-tägigen Versuches wurde bei den Ferkel, denen das Eiweiss entzogen worden war, ein schnelles Absinken der Serumeiweisskonzentrationen festgestellt. Die grössten Verluste bezogen sich auf Albumin und die beiden $\beta$-Globulinfraktionen. Das Niveau des $\gamma$-Globulins stieg an, jedoch bedeutend langsamer als bei der Kontrollgruppe. In einer zweiten Periode von 42 Tagen erhielte die Hälfte der Tiere auf eiweissloser Diät Kontrollfutter. Bei den Ferkeln deren Futter während der zweiten Periode von 42 Tagen Eiweiss enthielt, erreichten die Konzentrationen aller Serumeiweissfraktionen - mit Ausnahme des $\gamma$-Globulins - das Niveau der Kontrolltiere bis zum Ende der Untersuchung. Die Ferkel mit eiweissloser Diät zeigten weiteren Verlust von Albumin, eine Verminderung einiger Fraktionen des $\alpha$-Globulins und das Aufhören der reinen $\gamma$-Globulinsynthese. Die Trends welche mittels Messungen von eiweissgebundenen Kohlehydraten beobachtet wurden, waren - ähnlich denjenigen die bei der Bestimmung von Polypeptiden erhalten wurden - mehr quantitative als qualitative Veränderungen in dem Serumeiweiss. Die Reduktion in den Konzentrationen der Serumlipide wird durch den Verlust von $\alpha$ - und $\beta$-Lipoeiweissen erklärt. Die Ferkel denen Eiweiss entzogen worden war haben ihr anfängliches Körpergewicht beibehalten, während ein ständiger Gewichtsverlust bei der total ausgehungerten Gruppe und ein ständiger Gewichtszuwachs bei der Kontrollgruppe festgestellt werden konnte.

\section{SAMMENDRAG}

Nogle virkninger af proteinmangel hos voksende svin. I. Serum protein systemet.

Der blev ikke fundet signifikant forskel i serumproteinkoncentrationen mellem totalt fastende grise og kontroldyr, der fik et semisyntetisk foder indeholdende mælkeproteiner. Serumlipoidindholdet steg $i$ inanitionsgruppen. Hos grise på proteinfrit foder faldt serumproteinkoncentrationen hurtigt i den første fors $\emptyset$ gsperiode på 42 døgn. Tabet var st $\varnothing$ rst $i$ albumin og $i$ to $\beta$-globulinfraktioner. $\gamma$-globulinkoncentrationen steg, men meget langsommere end i kontrolgruppen. Til halvdelen af de proteinmanglende dyr blev der herefter, $i$ endnu en fors $\varnothing$ gsperiode på 42 d $\emptyset \mathrm{gn}$, tilf $\varnothing \mathrm{rt}$ kontrolfoder. Undtagen for $\gamma$-globulins vedkommende steg koncentrationen af alle serumproteinkomponenter herved til samme niveau som hos kontroldyrene. I den gruppe grise, der $i$ anden fors $\emptyset$ gsperiode fortsatte på proteinfrit foder, blev der fundet yderligere tab af albumin, reduktion $i$ visse 
$\alpha$-globulinfraktioner og oph $\varnothing \mathbf{r}$ af netto $\gamma$-globulinsyntesen. Bestemmelse af proteinbundet kulhydrat viste samme tendens som polypeptidbestemmelserne, hvorfor forandringerne i serumproteinbilledet snarere skyldes kvantitative end kvalitative ændringer. Nedsættelse af serumlipoidkoncentrationen hos de proteinmanglende grise skyldes især nedsat $\alpha$ - og $\beta$-lipoproteinkoncentration. Grisene på proteinfrit foder opretholdt deres legemsvægt, medens der blev fundet fortsat vægttab hos de totalt fastende grise og en fortsat vægtfor $\varnothing$ gelse hos kontroldyrene.

(Received March 10, 1969). 